\title{
Means of expressing emotions in the engineering profession
}

\author{
I Shcherbakova ${ }^{1}, N$ Kovalchuk $^{1, *}$, and $M$ Timashova $^{1}$ \\ ${ }^{1}$ Don State Technical University, Gagarin sq., 1, Rostov on Don, 344003, Russia
}

\begin{abstract}
The paper examines the language means representing indignation emotion in art communication on the basis of material of the Russian and German languages. The purpose of the paper is to describe and analyze the language means of objectification of an emotional condition of indignation the artistic discourse in the author's and character's speech. To achieve the goal the following methods of research are used: descriptive, contextual and stylistic-pragmatic analyses and linguistic observation technique. Fiction texts of classical and modern literature in the Russian and German languages have served as the practical material for this research. It has been established that the emotional condition of indignation in the artistic discourse is expressed by verbal and non-verbal means through the direct nomination of this emotion, as well as by means of the description. The theoretical importance of the research lies in the studying of the mechanisms of linguistic indignation emotion expression means in the artistic discourse.
\end{abstract}

\section{Introduction}

The study of the emotionality expression peculiarities in language and speech is one of the fundamental problems in the research of domestic and foreign linguists. At the present stage of development of linguistics as a science, emotiology has emerged and is actively developing as a separate branch of linguistics, which is aimed at studying the laws of language representation of emotions.

Emotion is "an affective form of expression of moral feelings (in contrast to motives being the volitional form of their expression). If a feeling is a stable subjective attitude of a person to something (love for the Motherland or for another person, hatred for the enemy), then an emotion is the experience of a particular feeling at a certain moment, in a specific situation" [1].

According to The "Great psychological dictionary", emotions are understood as "a special class of mental processes and states associated with instincts, needs and motives that are reflecting the significance of various phenomena and situations affecting an individual in the form of a direct experience (satisfaction, joy, fear, etc.) [2].

Accompanying almost any of the subject's activity manifestation, emotions serve as one of the main mechanisms of internal regulation of mental activity and human behavior" [3].

\footnotetext{
* Correspodning author: nadezhda_kovalchuk_2012@mail.ru
} 
According to the famous scientist V. I. Shakhovsky, emotions are one of the "forms of reflection of the world that displays not the objects and phenomena of the real world, but the relations in which they refer to a Person, i.e., not the properties of objects and phenomena, but their significance for human life" [4].

In other words, emotions express the subject's attitude to the world around him/her, his/her feelings and experiences [5].

\section{Methods, techniques and technologies used}

In our work, we used various methods, including theoretical; empirical (observation, questioning).

\section{The main part}

In linguistics, there are three ways to verbalize emotions - language nomination, expression and description [6]. Respectively, there are three vocabulary groups: lexical units that denote, express and describe emotions [7].

Thus, the language means of emotions objectification should include means that name emotions, means that express emotions, and means that describe emotions [8].

As it was rightly pointed out by Yakimenko E. A., "An emotion can be neither communicative act nor the act of speech [9].

An emotion is realized in a communicative act, the linguistic personality expresses it in a speech act using lexical, syntactic means or non-verbal communication (non-linguistic means)" [10].

The research interest in studying the features of objectification of the emotion of indignation in artistic discourse is determined by the fact that "all fiction is a depository of emotions: it describes emotional categorical situations, verbal and non-verbal emotional behavior of a person, as well as ways, means and methods of communication of emotions [11].

It captures the emotional, the specific and the individual experiences of a person and the ways of his emotional reflection" [12].

The emotional state of a person is fully reflected in the literary text [13]. It is in the literary text that "a certain mental stereotype of emotional situations is reflected, which is associated with national, social, historical and other factors that determine the behavior of an individual" [14].

The description of ways and means of representing the emotions and emotional state of a character allows us to identify the main patterns of formation of the emotional content of a literary text [15].

The emotion of indignation is included in the conceptual field of the basic emotion of anger and it can be expressed by both linguistic and non-linguistic means in artistic discourse. According to various lexicographic sources, "perturbation" is defined as follows: "extreme discontent, indignation, anger" [16] irritation, indignation " [17]. In German, the word «die Empörung» denotes 1. von starken Emotionen begleitete Entrüstung als Reaktion auf Verstöße gegen moralische Konventionen. 2. Aufstand, Rebellion, Meuterei.

The analysis of dictionary definitions of the lexeme "indignation" allowed us to conclude that the emotion of indignation is an external manifestation of anger and rage.

The emotion of indignation belongs to the group of emotions that in its turn refers to "the psychological sphere of human existence, it is born under the influence of external factors, being a response to the subjective reaction of an individual to environmental stimuli, it has greater dynamism, and it is easily transformed". 
In artistic discourse, the emotional state of indignation can be expressed in verbal and non-verbal ways at the lexical, morphological, and syntactic linguistic levels.

The emotion of indignation is represented by emotionally-colored vocabulary in speech acts, for example, the use of invectives such as scum, scoundrel, pig, scum, cattle, etc. Here there are some examples:

Seven forty-five. Edgar, you're a scoundrel... Neurotic brute [Paley Marina. Tribute to the Salamander].

in German:

Eduard sieht aus, als ob er einen Schlaganfall kriegen wird. «Gib die Marken her, Schuft», - sagt er dumpf [Remarque Erich Maria. Der schwarze Obelisk],

At the phonetic level, the emotion of indignation is transmitted by intonation.

"Stop, you b-brute," shouted the gentleman, jumping up and down in his dressing gown, which was put on one sleeve, and seizing the dog by the legs; " Zina, hold this scoundrel by the collar. [Bulgakov M. A. Dog's heart]. In this example, there is a change in the sound and letter composition.

The punctuation marks used to convey the emotional state of indignation should also be noted. For example, when a chararacter can't find the right linguistic means at the moment of indignation, his speech is interrupted by pauses, which are indicated by ellipses in writing.I asked you for no bed-place!.. (Gasping with indignation.) I said... I'm not simple!. how can you... I am ... [Paley Marina. Long Distance, or Slavic accent.].

The external manifestation of the emotional state of a character is revealed by the author's words, i.e. the author's speech. One of the lexical tools that call the emotion of anger in the author's speech is the verbs of speaking (yell, shout, explode, growl, get angry, resent, hiss, wheeze, schreien, sich ärgern, mosern, wüten, knurren, zischen, empören etc. For example,

“-Jlep, you don't understand anything at all! Kireeva hissed with indignation. - They are the ones who will curse you "[Simkina Marina. You'll Wake up.].

In German, “Er taumelte zurück; aber im selben Augenblick fuhr hinter einem Baume Schwester Julchen wie ein schwarzes Teufelchen hervor, warf sich, zischend vor Wut, auf Tony, riß ihr den Hut vom Kopf und zerkratzte ihr die Wangen aufs jämmerlichste..." [Mann Thomas. Buddenbrooks].

The emotional state of indignation is revealed through descriptions of non-verbal components of speech. By non-verbal speech behavior of a character, we mean "the words of the author (the author's speech) - the non-verbal part of the character's speech behavior captured in time and fixed in the written form by language means".

According to E. P. Ilyin, emotions are "a psychophysiological phenomenon, so the occurrence of a person's experience can be judged both by the person's self-report on the state they are experiencing, and by the nature of changes in vegetative indicators (heart rate, blood pressure, respiratory rate, etc.) and psychomotor skills: facial expressions, pantomime (posture), motor reactions, voice".

The emotional state of indignation in artistic discourse is revealed through facial expressions, gestures, and body movements. For example: "You bastard, you locked it," Tanya thought, and slammed her fists with all her might on the glass inset [Ulitskaya Lyudmila. Kukotsky's Incident].

Non-verbal means of describing the emotion of indignation include the description of the following signs: redness / paleness / darkening of the face; tight compression of the lips; lowering and narrowing of the eyebrows; dilation of the nostrils; raising / lowering of the voice; changing in the pace of speech, gestures, stomping.

For example: Vera's breath caught in her throat with the indignation of [Rubin Dean. On the Sunny side of the street]. in German: Momos Wangen begannen vor Empörung zu glühen [Ende Michael. Momo]. 


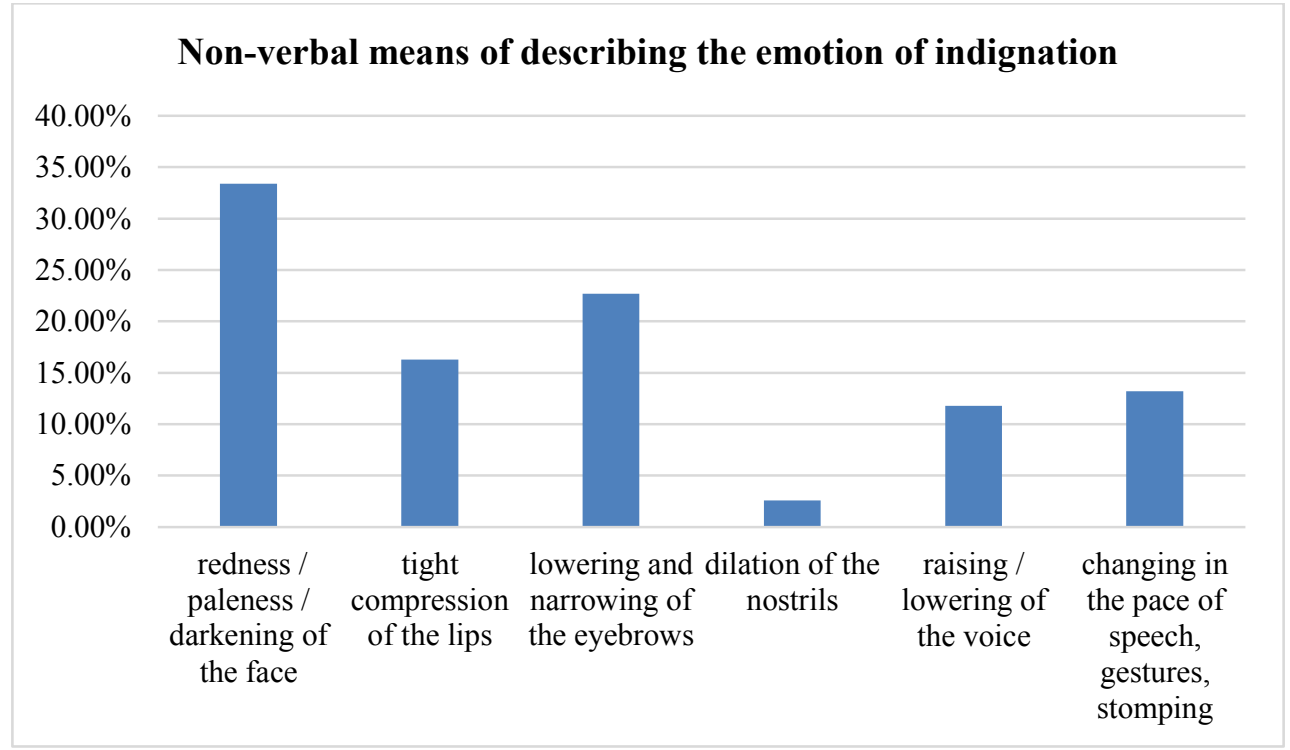

Fig. 1. Non-verbal means of describing the emotion of indignation.

Physiological changes are expressed by means of phraseological units, for example: She can't utter a word in her indignation; nasty muddy bubbles are coming out of her mouth, which no longer fit into the fairy tale [Paley. Commemoration].

In German: Sie zog nur mit geöffneten Nasenflügeln heftig die Luft ein und hob die Schultern empor [Mann Thomas. Buddenbrooks.].

Thus, the emotional state of indignation in the character's non-verbal speech behavior is explicated by psychophysiological, physiological, and behavioral changes.

The psychosomatic state of a person is revealed with the help of lexical units describing the eyes, mouth, body shivering, change in skin colour, breath.

For example: he was just shaking with indignation, she opened her mouth wide with indignation, cheeks puffed out with indignation, indignation turned blue, growing rather red with indignation, blushing with indignation, he jumped up from indignation, shaking with indignation, indignation caused her hands to shake, his fists are compressed with indignation, sweating with indignation, spluttering with indignation, roared in outrage, pissed off, threw his hands up in anger, vor Empörung glühen, mir auch vor Entsetzen das Herz im Halse schlug, seinen Mund in Entrüstung geöffnet hielt, sprang voller Zorn auf und rief laut, puterrot vor Zorn, zitternd, die Lippen bebten vor Zorn etc. 


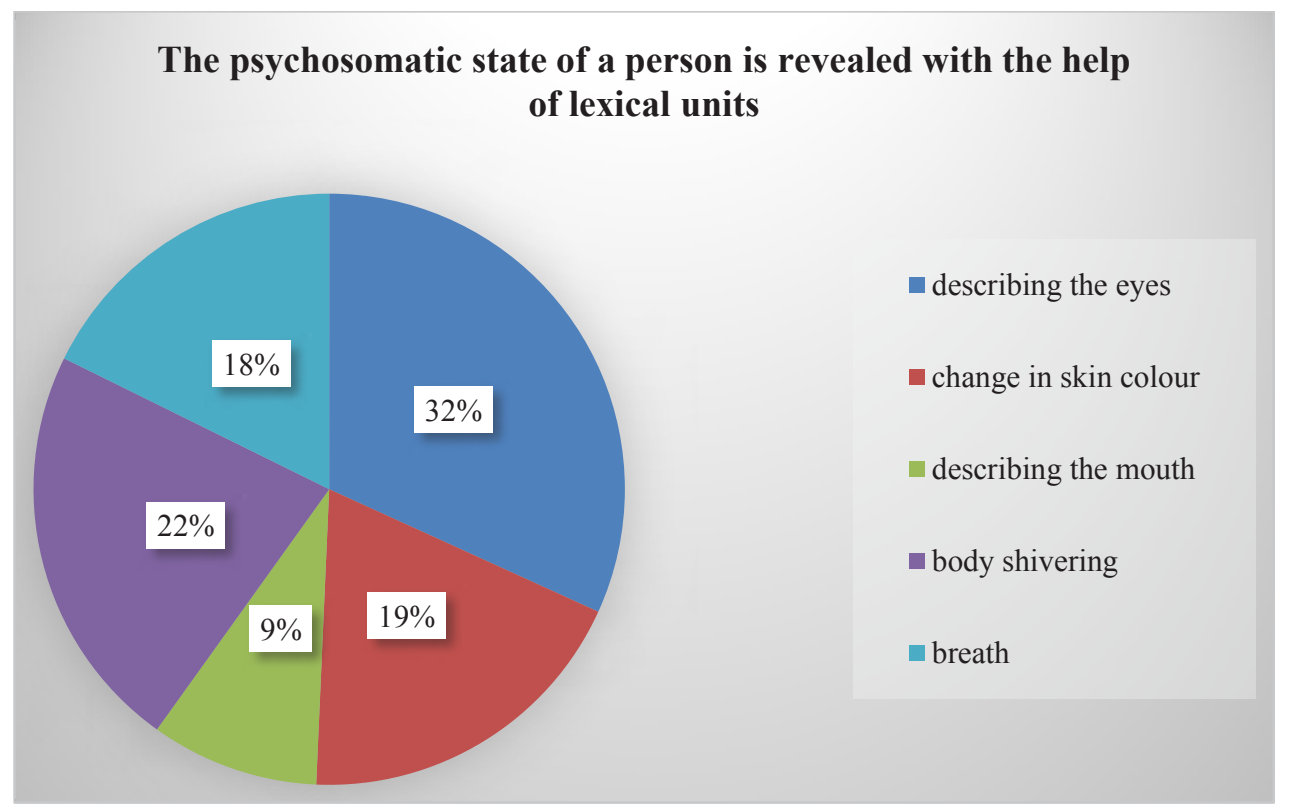

Fig. 2. The psychosomatic state of a person is revealed with the help of lexical units.

\section{Conclusion}

The emotional state of indignation in artistic discourse is explicated by various linguistic means: emotionally-colored vocabulary, reduced vocabulary, syntactic repetitions, interjections, exclamations, ellipsis, etc. In the representation of the emotional state of perturbation in non-verbal speech behavior, the following components of non-verbal speech were identified: prosodics (tempo, timbre, pitch, volume), kinesics (facial expressions, gestures, postures), and proxemics (spatial mutual position of communicants during communication).

\section{References}

1. D. Oudin-Doglioni, M.-C. Gay, M.-P. Lehougre, F. Galactéros, J.-B. Arlet, Annales Medico-psychologiques, revue psychiatrique 177(6), 517-525 (2019)

2. T.L. Muzychuk, Nonverbal component of the discourse of the character in the model and language representation. Diss, abstract for the Cand. of Philology degree (Astrakhan, 2013)

3. A. Kotov, N. Arinkin, L. Zaidelman, A. Zinina, A. Filatov, Advances in Intelligent Systems and Computing 636, 126-132 (2018)

4. A.P. Tikhonova, S.R. Makerova, S.A. Sasina, E.N. Orekhova, Z.R. Khachmafova, Mediterranean Journal of Social Sciences 6(3), 115-120 (2015)

5. Z.R. Khachmafova, I.S. Karabulatova, S.A. Lyausheva, E.N. Luchinskaya, G.V. Osipov, Mediterranean Journal of Social Sciences 6(3), 476-481 (2015)

6. E.A. Yakishchenko, An indignant language person: communicative and pragmatic approach (based on English and French languages), Diss, for the Cand. of Philology degree (2014) 
7. T.F. Efremova, New Dictionary of the Russian language. Explanatory and wordbuilding (2017) http://www.classes.ru/all-russian/russian-dictionary-Efremova-term10312.htm

8. W.M. Abdel, B.C. Domain, IEEE/ACM Transactions on Audio, Speech and Language Processing 26(12), 2423-243 (2018)

9. J. Hou, C. Zhang, R.A. King, International Review on Public and Nonprofit Marketing 15(1), 25-47 (2018)

10. I.S. Karabulatova, Z.R. Khachmafova, M.M. Bricheva, T.T. Nescheretova, A.K. Bersirova, Review of European Studies 7(6), 35-45 (2015)

11. A.V. Olyanitch, Z.R. Khachmafova, S.R. Makerova, M.P. Akhidzhakova, T.A. Ostrovskaya, Lecture Notes in Networks and Systems 87, 442-448 (2020)

12. E.T. Rolls, Neuropsychologia 128, 14-43 (2019)

13. A.V. Olyanitch, Z.R. Khachmafova, S.R. Makerova, M.P. Akhidzhakova, T.A. Ostrovskaya, Communications in Computer and Information Science 1084, 109-121 (2019)

14. I.S. Karabulatova, S.A. Lyausheva, Z.R. Khachmafova, I.P. Savchuk, O.S. Shibkova, Astra Salvensis 6(12), 737-744 (2018)

15. T.A. Ostrovskaya, Z.R. Khachmafova, S.A. Lyausheva, I.S. Karabulatova, G.V. Osipov, Mediterranean Journal of Social Sciences 6(3), 147-154 (2015)

16. A.V. Olyanitch, M.P. Akhidzhakova, Z.R. Khachmafova, B.N. Akhidzhak, E.A. Gashimov, Lecture Notes in Networks and Systems 129, 3-11 (2020)

17. Z.R. Khachmafova, I.S. Karabulatova, S.V. Serebriakova, A.V. Zinkovskaya, E.N. Ermakova, Pertanika Journal of Social Sciences and Humanities 25, 137-150 (2017) 